\title{
Review Article \\ Utilization of Nanomaterials in Target Oriented Drug Delivery Vehicles
}

\author{
T. K. Mandal*, V. Patait \\ ICFAI Tech School, ICFAI University, Rajawala Road, Central Hope Town, Selaqui, Dehradun- \\ 248011, India
}

Received 19 June 2020, accepted in final revised form 11 October 2020

\begin{abstract}
The present investigation deals with the fundamentals of nanorobots, its fabrication, and possible utilization in a different target-oriented drug delivery vehicles. Details of various types of nanorobots and their specific applications are studied in this research. The use of nanorobots in cancer treatment, target-oriented drug delivery, medical imaging, and in new health sensing devices has also been studied. The mechanism of action of nanorobots for the treatment of cancerous cells as well as the formulation and working functions of some recently studied nanorobots are investigated in this work. This paper reviews the research in finding the suitable nanorobotic materials, different fabrication processes of nanorobots, and the current status of application of nanorobots in biomedical, especially in the treatment of cancers. Superparamagnetic iron oxide nanoparticles (SPIONs) have been observed to be used as novel drug delivery vehicle materials. The future perspectives of nanorobots for the utilization in drug delivery are also addressed herewith.
\end{abstract}

Keywords: Nanorobot; Drug delivery; Cancer treatment; SPIONs; Nanoswimmers.

(C) 2021 JSR Publications. ISSN: 2070-0237 (Print); 2070-0245 (Online). All rights reserved. doi: http://dx.doi.org/10.3329/jsr.v13i1.47690

J. Sci. Res. 13 (1), 299-316 (2021)

\section{Introduction}

Miniaturizing devices to the nanoscale creates a wealth of new possibilities in nanobiotechnology and nanomedicine, such as targeted drug delivery platforms [1]. A nanorobot is a tiny machine, with dimension in nanoscale, designed to perform a specific task. Nanorobots are designed to perform at the atomic or molecular level. Nanorobots are used in cancer treatment, target-oriented drug delivery, medical imaging, new sensing devices, information storage devices, new energy systems, super-strong metamaterials, smart windows and walls, ocean-cleaning microsponges, molecular assembler, health sensors, etc. [1-8]. But, the major application of it is in nanomedicine [2]. They have applications in the diagnosis and treatment of diabetes, early detection, and treatment of cancer, cellular nanosurgery and gene therapy [3-6]. Because magnetism has been widely

\footnotetext{
Corresponding author: dr.mandal@iudehradun.edu.in
} 
used in medical nanorobotics, magnetic nanoparticles (MNPs) in particular have shown to be well suited for this purpose. $\mathrm{Fe}_{3} \mathrm{O}_{4}$ and $\gamma-\mathrm{Fe}_{2} \mathrm{O}_{3}$ in particular, are used extensively in medical nanorobotic applications due to their low toxicity and their known pathways of metabolism, making these materials attractive for nanorobotic agents designed for medical applications [5]. In medical nanorobotics, $\mathrm{Fe}_{3} \mathrm{O}_{4} \mathrm{MNPs}$ are generally preferred to $\gamma-\mathrm{Fe}_{2} \mathrm{O}_{3}$ MNPs due to its higher saturation magnetization. The magnetization state for a ferromagnetic material is the result of the alignment of microscopic regions in the material known as magnetic domains or magnetic moments. Guiding magnetic iron oxide nanoparticles with the help of an external magnetic field to its target is the principle behind the development of superparamagnetic iron oxide nanoparticles (SPIONs) as novel drug delivery vehicles [6]. SPIONs are small synthetic $\gamma-\mathrm{Fe}_{2} \mathrm{O}_{3}$ or $\mathrm{Fe}_{3} \mathrm{O}_{4}$ particles with a core ranging between $10-100 \mathrm{~nm}$ in diameter. These magnetic particles are coated with certain biocompatible polymers, such as dextran or polyethylene glycol, which provide chemical handles for the conjugation of therapeutic agents and also improve their blood distribution profile. The recent research on SPIONs is increasing because of their use as diagnostic agents in magnetic resonance imaging as well as for drug delivery vehicles. Delivery of anticancer drugs by coupling with functionalized SPIONs to their targeted site is one of the important areas of research in the development of cancer treatment methods [6]. Magnetic helical nanorobots can perform 3D navigation in various liquids with a submicrometer precision under low-strength rotating magnetic fields $(<10 \mathrm{mT})$ [7]. Since magnetic fields with low strengths are harmless to cells and tissues, magnetic helical nanorobots are promising tools for biomedical applications, such as minimally invasive surgery, cell manipulation and analysis, and targeted therapy. Qiu and Nelson [7] reviewed on magnetic helical micro/nanorobots, including their fabrication, motion control, and further functionalization for biomedical applications MNPs can be used as the primary method of physically directing aptamer-MNPs and drug payloads to their target cells or tissues as well by use of an external magnetic field which drags the MNPs and their complexes to any desired and accessible location in the body [6] where aptamerMNPs could act as nanosurgeons [8]. A far less invasive approach for the treatment of cancer is based on using a carrier, i.e. a nanorobot that can be functionalized and manipulated wirelessly to target cancer cells [1]. The most common strategy currently being pursued by researchers relies on injecting the nanorobots intravenously, guiding them by means of magnetic fields and field gradients, and, finally, activating them to promote the diffusion of drugs into the affected tissue. MNPs such as nanoparticles (NPs) and nanowires (NWs) are promising candidates for drug delivery platforms, especially for the treatment of cancer. The use of magnetic NWs has some advantages over the use of NPs, primarily because of NWs exhibit both a high aspect ratio and magnetic shape anisotropy. Moreover, large arrays of ferromagnetic NWs can be controllably and reliably fabricated.

The researchers from Polytechnique Montréal, Université de Montréal and McGill University have just achieved a spectacular breakthrough in cancer research [9]. They have developed new nanorobotic agents, capable of navigating through the bloodstream, 
to administer a drug with precision by specifically targeting the active cancerous cells of tumor (Fig. 1). This way of injecting medication ensures the optimal targeting of a tumor and avoids jeopardizing the integrity of organs and surrounding healthy tissues. As a result, the drug dosage that is highly toxic for the human organism could be significantly reduced.

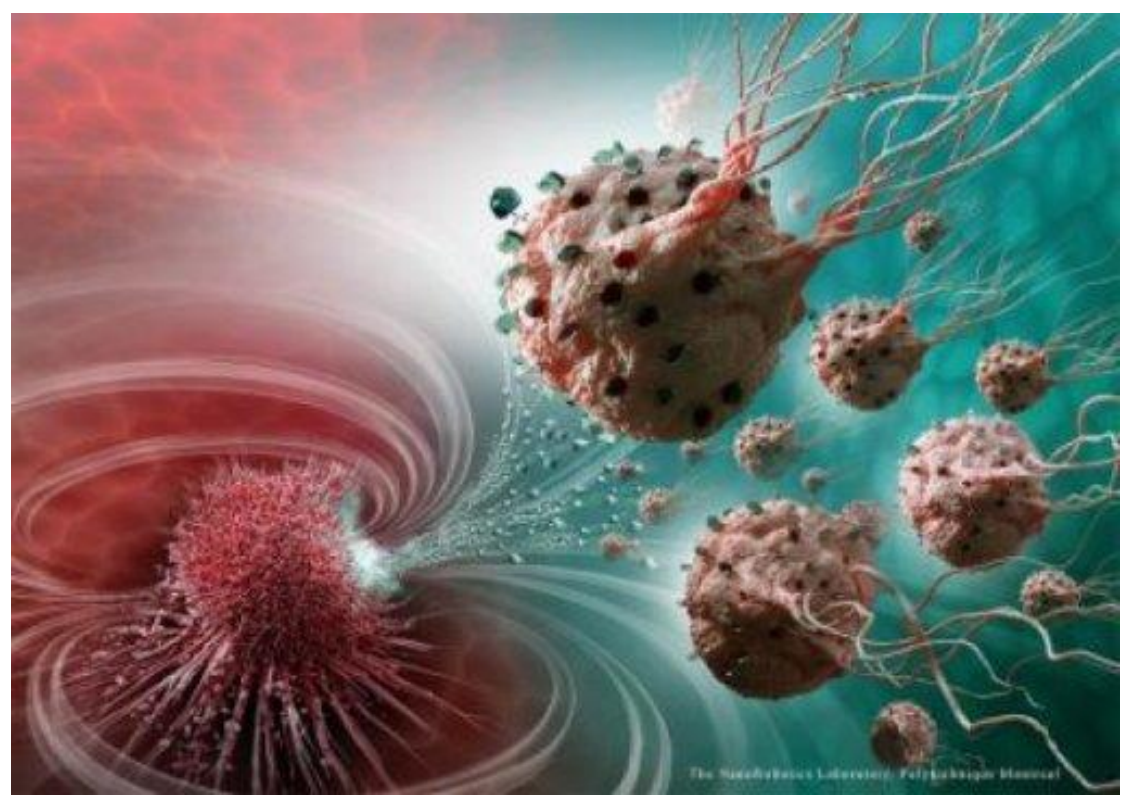

Fig. 1. The legions of nanorobotic agents are actually composed of more than 100 million flagellated bacteria - and therefore self-propelled -and loaded with drugs that moved by taking the most direct path between the drug's injection point and the area of the body to cure. Credit: Montréal Nanorobotics Laboratory [9].

Oxygen-depleted hypoxic regions in the tumor are generally resistant to therapies $[9,10]$. Although nanocarriers have been used to deliver drugs, the targeting ratios have been very low. Felfoul et al. [9] showed that the magneto-aerotactic migration behavior [11] of magnetotactic bacteria [12], magnetococcus marinus strain MC-1 [13], can be used to transport drug-loaded nanoliposomes into hypoxic regions of the tumor. In their natural environment, MC-1 cells, each containing a chain of magnetic iron-oxide nanocrystals [14], tend to swim along local magnetic field lines and towards low oxygen concentrations [15] based on a two-state aerotactic sensing system [11]. They showed that when MC-1 cells bearing covalently bound drug-containing nanoliposomes were injected near the tumor in severe combined immunodeficient beige mice and magnetically guided, up to 55 $\%$ of MC-1 cells penetrated into hypoxic regions of HCT116 colorectal xenografts. Approximately 70 drug-loaded nanoliposomes were attached to each MC-1 cell. Their results suggested that harnessing swarms of microorganisms exhibiting magneto- 
aerotactic behaviour can significantly improve the therapeutic index of various nanocarriers in tumour hypoxic regions.

To move around, bacteria used by Martel's team rely upon two natural systems [9]. A kind of compass created by the synthesis of a chain of MNPs allows them to move in the direction of a magnetic field, while a sensor measuring oxygen concentration enables them to reach and remain in the tumor's active regions. By harnessing these two transportation systems and by exposing the bacteria to a computer-controlled magnetic field, researchers showed that these bacteria could perfectly replicate artificial nanorobots of the future designed for this kind of task. 'This innovative use of nano-transporters will have an impact not only on creating more advanced engineering concepts and original intervention methods, but it also throws the door wide open to the synthesis of new vehicles for therapeutic, imaging and diagnostic agents,' Martel adds. 'Chemotherapy, which is so toxic for the entire human body, could make use of these natural nanorobots to move drugs directly to the targeted area, eliminating the harmful side effects while also boosting its therapeutic effectiveness.

The objective of this research is to study some details on nanorobots, their fabrication techniques, and important applications in target-oriented drug delivery vehicles, especially in the treatment of cancers.

\section{Types of Nanorobots}

Nanorobots may be of different types. Some of these are represented in Table 1.

Table1: Different types of nanorobots.

\begin{tabular}{|c|c|c|}
\hline $\begin{array}{l}\text { Type of } \\
\text { Nanorobots }\end{array}$ & Details of nanorobots & References \\
\hline Smallest engine & $\begin{array}{l}\text { A group of physicists from the University of Mainz in } \\
\text { Germany recently built the smallest engine ever created from } \\
\text { just a single atom. Like any other engine, it converts heat } \\
\text { energy into movement - but it does so on a smaller scale than } \\
\text { seen before. The atom is trapped in a cone of electromagnetic } \\
\text { energy and lasers are used to heat it up and cool it down, which } \\
\text { causes the atom to move back and forth in the cone-like an } \\
\text { engine piston. For example, Gluconacetobacter xylinus which } \\
\text { is also known as Acetobacter xylinum is used as a nanoengine } \\
\text { to formulate the three-dimension honeycomb structure of } \\
\text { cellulose. Gluconacetobacter has got the property that it can } \\
\text { move at speed of } 2 \mu \mathrm{m} \text { per min at } 25{ }^{\circ} \mathrm{C} \text {. It gets that speed } \\
\text { when the secretion of cellulose microfibrils takes place. }\end{array}$ & {$[16,17]$} \\
\hline $\begin{array}{l}\text { 3D-motion } \\
\text { nanomachines } \\
\text { from DNA }\end{array}$ & $\begin{array}{l}\text { Mechanical engineers at Ohio State University have designed } \\
\text { and constructed complex nanoscale mechanical parts using } \\
\text { 'DNA origami' proving that the same basic design principles } \\
\text { that apply to typical full-size machine parts can now also be } \\
\text { applied to DNA and can produce complex, controllable } \\
\text { components for future nanorobots. Peng et al. fabricated a } \\
\text { nanomachine which looks like orbitron and based upon } 3\end{array}$ & {$[18,19]$} \\
\hline
\end{tabular}




\begin{tabular}{|c|c|c|}
\hline & $\begin{array}{l}\text { dimensional DNA structure. To make that they tried to } \\
\text { interlock the structure of double DNA rings by two single- } \\
\text { stranded DNA. It was then applied to microRNA. MicroRNA } \\
\text { confirmed the changes in 3-dimensional space of it and with } \\
\text { this the combination they were able to do the diagnosis of } \\
\text { cancer. }\end{array}$ & \\
\hline Nanoswimmers & $\begin{array}{l}\text { ETH Zurich and Technion researchers have developed an } \\
\text { elastic nanoswimmers polypyrrole NWs about } 15 \mu \mathrm{m} \text { long and } \\
200 \mathrm{~nm} \text { thick that can move through biological fluid } \\
\text { environments at almost } 15 \mu \mathrm{m} \text { per sec. The nanoswimmers } \\
\text { could be functionalized to deliver drugs and magnetically } \\
\text { controlled to swim through the bloodstream to target cancer } \\
\text { cells. Nour Zoaby et al. developed the bacteria-based drug } \\
\text { delivery system which can automatically detect, move, and can } \\
\text { target the cancerous cell. The bacteria will be loaded with the } \\
\text { anti-cancerous drug named doxorubicin and can reach the } \\
\text { cancerous cells and treat it. Xiahui demonstrated the approach } \\
\text { of loading, transportation, and release of drugs by the } \\
\text { nanoswimmers by the application of a magnetic field from the } \\
\text { outside. The nanoswimmers have been derived from Spirulina. } \\
\text { It will perform all the operation i.e. load, transport, and release } \\
\text { the drug material. }\end{array}$ & [20-22] \\
\hline $\begin{array}{l}\text { Ant-like } \\
\text { nanoengine with } \\
100 \times \text { force per } \\
\text { unit weight }\end{array}$ & $\begin{array}{l}\text { University of Cambridge researchers have developed a tiny } \\
\text { engine capable of a force per unit-weight nearly } 100 \text { times } \\
\text { higher than any motor or muscle (Fig. 2). The new nanoengines } \\
\text { could lead to nanorobots small enough to enter living cells to } \\
\text { fight disease. Baumberg from the Cavendish Laboratory, led } \\
\text { the research, has named the devices 'actuating nanotransducers' } \\
\text { (ANTs). 'Like real ants, they produce large forces for their } \\
\text { weight.' This has been claimed as, 'The world's tiniest, most } \\
\text { powerful nanoengine.' }\end{array}$ & {$[23]$} \\
\hline $\begin{array}{l}\text { Sperm-inspired } \\
\text { microrobots }\end{array}$ & $\begin{array}{l}\text { A team of researchers at the University of Twente } \\
\text { (Netherlands) and German University in Cairo (Egypt) has } \\
\text { developed sperm-inspired microrobots, which can be controlled } \\
\text { by oscillating weak magnetic fields. They will be used in } \\
\text { complex micro-manipulation and targeted therapy tasks. } \\
\text { Emanuela et al. developed a genosensor which is basically an } \\
\text { optical fiber-based sensor. Optical fiber is used to create a } \\
\text { probe which can detect APTES-DNA. DNA origami is used to } \\
\text { detect a particular sequence of the DNA with the help of a } \\
\text { probe. DNA works as a nanorobot over here and can cargo the } \\
\text { required material to the desired location. }\end{array}$ & {$[24,25]$} \\
\hline $\begin{array}{l}\text { Bacteria-powered } \\
\text { robots }\end{array}$ & $\begin{array}{l}\text { Drexel University engineers have developed a method for using } \\
\text { electric fields to help microscopic bacteria-powered robots } \\
\text { detect obstacles in their environment and navigate around } \\
\text { them. Uses include delivering medication, manipulating stem } \\
\text { cells to direct their growth, or building a microstructure. Hyo et } \\
\text { al. presented the study to treat the cancerous cell by the } \\
\text { nanorobots. These nanorobots will be used to treat the } \\
\text { tumor present in the breast tissue. They have also done the } \\
\text { simulation work to show the possible structure of the } \\
\text { nanorobot, detection of the cancerous cells a treatment by the }\end{array}$ & {$[26,27]$} \\
\hline
\end{tabular}




\begin{tabular}{|l|l|l|}
\hline & nanorobot. & \\
\hline Nanorockets & $\begin{array}{l}\text { Several groups of researchers have recently constructed a high- } \\
\text { speed, remote-controlled nanoscale version of a rocket by } \\
\text { combining NPs with biological molecules [Fig 3]. Researchers } \\
\text { hope to develop the rocket so it can be used in any } \\
\text { environment; for example, to deliver drugs to a target area of } \\
\text { the body. }\end{array}$ & \\
\hline Nanomotor & $\begin{array}{l}\text { Ran } \text { et al. described that when Cu-Pt based nanorod is placed in } \\
\text { a solution of } \mathrm{Br}_{2} \text { or } \mathrm{I}_{2} \text { does behave as a nanobattery and } \\
\text { generate a movement. This movement is generated due to the } \\
\text { redox reaction. The rod also generates rotatory motion due to } \\
\text { the iron gradient which is generated when it is placed in a } \mathrm{Br}_{2} \\
\text { solution. }\end{array}$ & \\
\hline
\end{tabular}

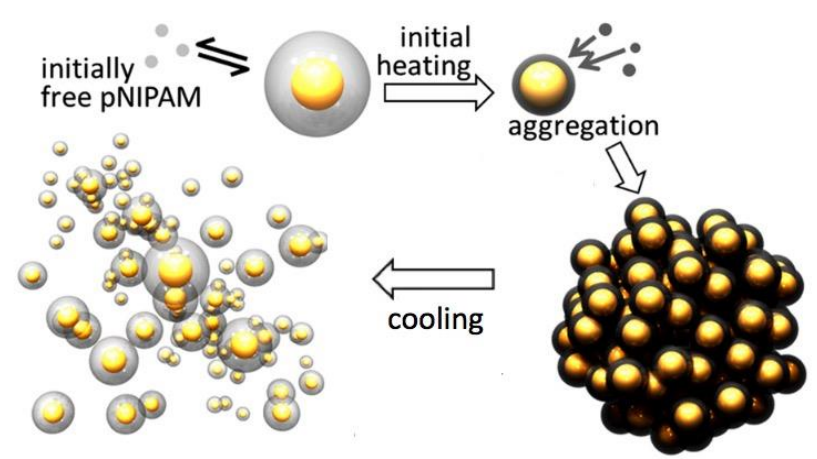

Fig. 2. The ANT reversible cycle. Left: ANTs are created by adding a polymer (gray spheres) called PNIPAM to gold NPs (yellow). A blue-light laser then heats the ANT solution. When heated to 32 ${ }^{\circ} \mathrm{C}$ with a laser, the polymer NPs absorb large amounts of elastic energy in a fraction of a sec as the polymer coatings expel all the water from the gel and collapse, forcing the gold NPs to bind together into dehydrated tight clusters (right). When the device is cooled (by turning off the laser), the polymers rapidly take on water and expand. That strongly, rapidly, and explosively pushes the gold NPs apart - suddenly releasing energy, similar to the release of a tightly compressed spring. (credit: Tao Ding et al./PNAS, adapted) [20].

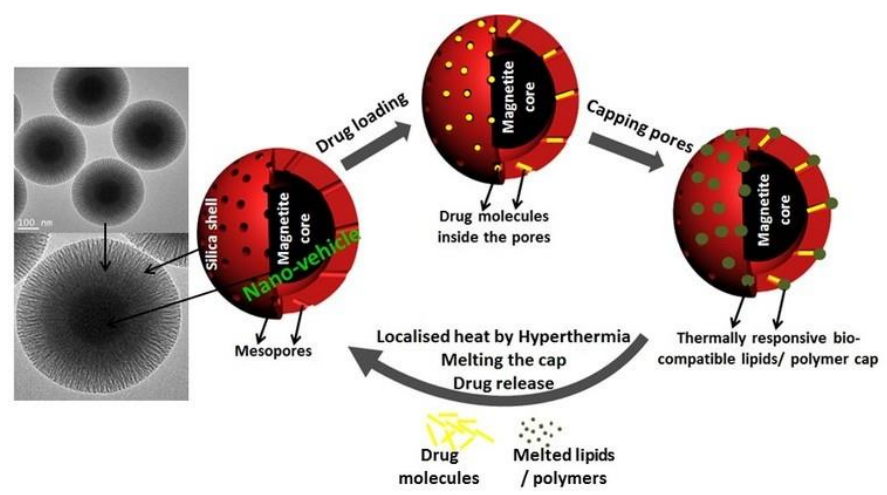

Fig. 3. Magnetic nano-vehicles for carrying drugs [28]. 


\section{Preparation of Nanorobotic Materials}

Highly aligned $\mathrm{ZnO}$ NWs have been grown by Mishra [2] using chemical synthesis [Fig. 4]. The piezoelectric power generators using $\mathrm{ZnO}$ NWs arrays on flexible plastic substrate might be able to harvest energy from the environment such as body movement (e.g., gestures, respiration, or locomotion). The ceramic or semiconductor substrates used for growing $\mathrm{ZnO} \mathrm{NWs}$ are hard, brittle, and cannot be used in the areas that require a foldable or flexible power source, such as implantable biosensors in muscles or joints, and power generator built-in walking shoes. Two advantages may be offered by this approach. One is the cost-effective, large-scale solution approach used to grow $\mathrm{ZnO} \mathrm{NW}$ arrays at a temperature lower than $80{ }^{\circ} \mathrm{C}$. The other is the large-degree of choice of flexible plastic substrates used for growing aligned $\mathrm{ZnO} \mathrm{NW}$ arrays, which could play an important role in flexible and portable electronics.

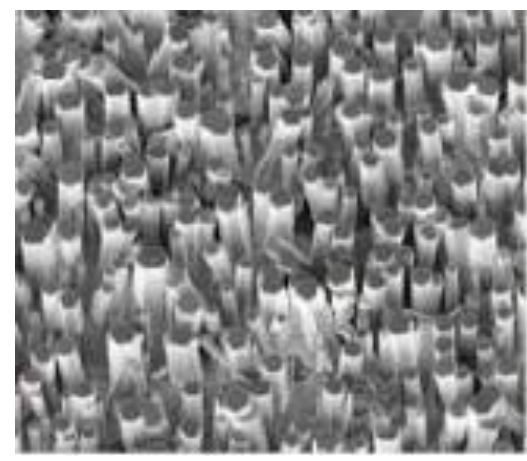

Fig. 4. SEM image of the as-synthesized ZnO NWs a chemical approach [2].

A new process to fabricate NWs was recently developed by growing them within anodic aluminum oxide (AAO) templates [1]. By controlling the pore size and the length of the AAO templates, as well as the composition of the electrolytes, many different types of ferromagnetic NWs can be fabricated. The AAO templates begin as an electron-beam evaporated layer of aluminum $(\mathrm{Al})$ on silicon. The $\mathrm{Al}$ is subsequently anodized in oxalic acid under current control to produce nanopores in the range of $85-100 \mathrm{~nm}$. Using pulsed electrodeposition, the ferromagnetic NWs are grown inside these pores. In turn, these NWs serve as catalysts for growing multiwalled carbon nanotubes (MWCNTs) using a low pressure chemical vapor deposition (LPCVD) process. The silicon provides a stable platform capable of withstanding the high temperatures encountered during the LPCVD process. The MWCNT coating has multiple utilities; primarily, its outer surface can be functionalized to attach to therapeutic molecules that specifically kill cancer cells. The coating also protects the ferromagnetic NWs from the environment, thus reducing the possibility of NWs toxicity when inside the body. Chandrashekaran et al. fabricated the chitosan curcumin $\mathrm{ZnO}$ (CCZ) nanomaterial to take on the Staphylococcus aureus and Escherichia coli bacteria. $0.5 \mathrm{~g}$ of curcumin was dissolved in $100 \mathrm{~mL}$ ethanol, $0.1 \mathrm{M}$ of 
hydrated zinc nitrate added to $1 \mathrm{~g}$ of chitosan. Chitosan is available in $100 \mathrm{~mL}$ of $1 \%$ of acetic acid. The formed solution of curcumin and ethanol was then added dropwise to the formed chitosan solution and then the mixture is stirred at $80{ }^{\circ} \mathrm{C}$ for $4 \mathrm{~h}$ to have a desirable solution. In a way, CCZ nanomaterial is overcoming bacterial resistance [30]. Gyanendra et al. presented a drug delivery vehicle based upon the Metal-Organic Framework (MOF-5) of $\mathrm{Zn}$. This vehicle is used to transport and deliver the metronidazole drug. MOF-5 was fabricated with the help of zinc acetate, $2.12 \mathrm{~g}$ terephthalic acid, $0.63 \mathrm{~g}$ was dissolved in $100 \mathrm{~mL}$ of dimethylformamide. Then the prepared sample goes through the heat treatment and placed in a vacuum for a limited time to achieve the required MOF-5. Adsorption of the drug was very much controlled by the $\mathrm{pH}$ of the local environment. [31]. Fatematossadat et al. presented the study upon the iron NPs as a drug delivery system. The iron NPs are Ag and Au coated so as to increase the adsorption of the drug. The magnetization and the magnetic moment of Fe particles made it more suitable for the drug delivery agent. The computational model shows that the adsorption of Mercaptopurine is better than the Cisplatin. The drug would be released over the cancerous cells as their $\mathrm{pH}$ would be less than the local environment. And these results pave the way for its utilization in biomedical applications [32]. Piyush et al. presented the semi aromatic polyester as a drug delivery vehicle. Alternate poly(CHO-co$\mathrm{PA})$ polymer synthesized from cyclohexene oxide (CHO) and phthalic anhydride (PA) monomers. With the help of these copolymers the curcumin (CUR) loaded NPs were obtained. The dialysis method was used to fabricate poly(CHO-alt-PA)-CUR NPs. CUR and copolymer were mixed first then it was dissolved in $2 \mathrm{~mL}$ of $12.5 \%(\mathrm{v} / \mathrm{v})$ methanol in chloroform solution. The obtained solution was then stirred dropwise in Milli Q water and then dialysis was done. Finally obtained polymer was tested haematologically, biologically, and pathologically. And when tested on mice for the elimination of cancerous cells as it has shown wonderful results [33]. Mengjie et al. presented the drug delivery system for Allergic rhinitis through the nasal cavity. Deoxycholatechitosanhydroxybutyl NPs with Cetirizine (CTZ) produced (CTZ: CDHBCs-NPs) this drug delivery system. Chitosan, 1,2-Butene oxide, deoxycholate (DOCA), CTZ hydrochloride $(\mathrm{CedH})$ etc. being used for the preparation of the system and its components. CedH was prepared by 1,2-butene oxide to chitosan connection. CDHBCs were synthesized by DOCA and CTZ groups combined with HBC group. CDHBC-29-NPs performed effective operation than the CDHBC-33-NPs and CDHBC-37-NPs [34]. Some of the nanorobotic materials, their properties, and applications are summarized in Table 2.

Table 2. Nanorobotic materials, their properties and applications.

\begin{tabular}{|l|l|l|}
\hline Materials/Nanomotors & Property improvement/application & Ref. \\
\hline Mesoporous silica NPs (MSNPs) & $\begin{array}{l}\text { Due to their unique intrinsic features, including } \\
\text { tunable porosity and size, large surface area, } \\
\text { structural diversity, easily modifiable chemistry } \\
\text { and suitability for functionalization, and } \\
\text { biocompatibility, MSNPs have been extensively } \\
\text { utilized as multifunctional nanocarrier systems. }\end{array}$ \\
\hline Gold nanostructures & Used as therapeutic cargo. Due to their ease of & {$[36]$} \\
\hline
\end{tabular}




\begin{tabular}{|c|c|c|}
\hline & $\begin{array}{l}\text { synthesis, straightforward } r \\
\text { functionalization, and non-toxicity, gold } \\
\text { nanostructures have emerged as powerful } \\
\text { nanoagents for cancer detection and treatment. }\end{array}$ & \\
\hline $\begin{array}{ll}\text { Size-controllable } & \text { supramolecular } \\
\text { nanoparticles (SNPs) } & \end{array}$ & $\begin{array}{l}\text { Supramolecular synthetic approaches are used } \\
\text { for the preparation of these materials. The } \\
\text { incorporation of various payloads, including } \\
\text { drugs, genes, and proteins, into SNPs, showed } \\
\text { improved delivery performance and enhanced } \\
\text { therapeutic efficacy for these therapeutic agents. }\end{array}$ & {$[37]$} \\
\hline Bionanomotors & $\begin{array}{l}\text { Nanoelectronics, photonics, bioengineering, and } \\
\text { drug delivery. }\end{array}$ & {$[38]$} \\
\hline Self-propelled nanomotors & $\begin{array}{l}\text { Artificial nanomotors can sense different } \\
\text { analytes and therefore pollutants or chemical } \\
\text { threats can be used for testing the quality of } \\
\text { water, selective removal of oil, and alteration of } \\
\text { their speeds, depending on the presence of some } \\
\text { substances in the solution in which they swim. } \\
\text { These self-powered remediation systems' could } \\
\text { be seen as a new generation of smart devices for } \\
\text { cleaning water in small pipes or cavities difficult } \\
\text { to reach with traditional methods. }\end{array}$ & {$[39]$} \\
\hline $\begin{array}{l}\text { Graphene-like 2D layered nanomaterials } \\
\text { (GLNs) }\end{array}$ & $\begin{array}{l}\text { It includes boron nitride nanosheets, graphitic- } \\
\text { carbon nitride nanosheets and transition metal } \\
\text { dichalcogenides. Recent advances of GLNs in } \\
\text { applications of biosensors and nanomedicine, } \\
\text { including electrochemical biosensors, optical } \\
\text { biosensors, bioimaging, drug delivery, and } \\
\text { cancer therapy. }\end{array}$ & {$[40]$} \\
\hline Self-powered micro/nanomotors & $\begin{array}{l}\text { Understanding the importance of material } \\
\text { selection in designing functional motors for } \\
\text { futuristic applications. }\end{array}$ & {$[41]$} \\
\hline Multifunctionalized iron oxide MNPs & $\begin{array}{l}\text { Synthesis and characterization of novel } \\
\text { multifunctionalized IONs with antiCD } 44 \\
\text { antibody and gemcitabine derivatives, and their } \\
\text { application for the selective treatment of CD44- } \\
\text { positive cancer cells. }\end{array}$ & {$[42]$} \\
\hline Nanomachine & $\begin{array}{l}\text { It consists of a magnetic nickel (Ni) nanotube } \\
\text { that contains a pH-responsive chitosan hydrogel } \\
\text { in its inner cavity. The chitosan inside the } \\
\text { nanotube serves as a matrix that can selectively } \\
\text { release drugs in acidic environments, such as the } \\
\text { extracellular space of most tumors. The Ni } \\
\text { nanotube allows the propulsion of the device by } \\
\text { means of external magnetic fields. As the } \\
\text { proposed nano-architecture integrates different } \\
\text { functional building blocks, this drug delivery } \\
\text { nanoplatform can be employed for carrying } \\
\text { molecular drug conjugates and for performing } \\
\text { targeted combinatorial therapies, which can } \\
\text { provide an alternative and supplementary } \\
\text { solution to current drug delivery technologies. } \\
\text { These wirelessly guided magnetic nanomachines }\end{array}$ & {$[43]$} \\
\hline
\end{tabular}




\begin{tabular}{|c|c|c|}
\hline & $\begin{array}{l}\text { are promising vectors for targeted drug delivery, } \\
\text { which have the potential to minimize the } \\
\text { interaction between anticancer agents and } \\
\text { healthy tissues. }\end{array}$ & \\
\hline Catalytic nanomotors. & $\begin{array}{l}\text { Catalytic nanomotors represent an exciting } \\
\text { technological challenge with the end goal being } \\
\text { practical functional nanomachines that can } \\
\text { perform a variety of tasks at the nanoscale. }\end{array}$ & {$[44]$} \\
\hline $\begin{array}{l}\text { Chemically powered self-propelled } \\
\text { nanomotors without moving parts that } \\
\text { rely on asymmetric chemical reactions } \\
\text { to affect directed motion. }\end{array}$ & $\begin{array}{l}\text { Such tiny motors are the subject of considerable } \\
\text { research because of their potential applications, } \\
\text { and a variety of synthetic motors has been made } \\
\text { and is being studied for this purpose. }\end{array}$ & {$[45]$} \\
\hline $\begin{array}{llr}\text { Hybrid chromium-doped zinc } & \text { gallate } \\
\text { core/mesoporous silica } & \text { shell } \\
\text { architecture } & & \\
\end{array}$ & $\begin{array}{l}\text { A persistent luminescence signal from these } \\
\text { doxorubicin-loaded mesoporous nanophosphors } \\
\text { opens a new way to highly sensitive detection in } \\
\text { vivo, giving access to the real-time } \\
\text { biodistribution of the carrier without any } \\
\text { autofluorescence from the animal tissues. }\end{array}$ & {$[46]$} \\
\hline $\begin{array}{l}\text { Biodegradable methoxy poly (ethylene } \\
\text { glycol)-poly (lactic acid) copolymer in } \\
\text { conjugation with curcumin }\end{array}$ & $\begin{array}{l}\text { The redox-sensitive polymeric conjugate } \\
\text { micelles could enhance curcumin delivery while } \\
\text { avoiding premature release, and achieving on- } \\
\text { demand release under the high glutathione } \\
\text { concentration in the cell cytoplasm. This } \\
\text { strategy opens new avenues for on-demand drug } \\
\text { release of nanoscale intracellular delivery } \\
\text { platforms that ultimately might be translated into } \\
\text { pre-clinical and future clinical practice. }\end{array}$ & {$[47]$} \\
\hline Nanosized polymer therapeutic agents. & $\begin{array}{l}\text { Development of a delivery system for breast } \\
\text { cancer cells using a microvector of drugs. Local, } \\
\text { controlled delivery of the drug will be achieved } \\
\text { with the advantage of a high concentration of } \\
\text { drug release at the target site while keeping the } \\
\text { systemic concentration of the drug low, thus } \\
\text { reducing side effects due to bioaccumulation. }\end{array}$ & {$[48]$} \\
\hline $\begin{array}{l}\text { Nanomotor based on zeolite or activated } \\
\text { carbon. }\end{array}$ & $\begin{array}{l}\text { New technological breakthroughs and greater } \\
\text { sophistication of nanoscale machines will lead to } \\
\text { rapid translation of the nanomotor research } \\
\text { activity into practical defense applications, } \\
\text { addressing the escalating threat of chemical and } \\
\text { biological warfare agents. }\end{array}$ & {$[49]$} \\
\hline $\begin{array}{l}\text { Graphene and graphene-based } \\
\text { nanostructures. }\end{array}$ & $\begin{array}{l}\text { The DNA translocations through nanopores in } \\
\text { graphene membranes toward the fabrication of } \\
\text { devices for genomic screening, in particular } \\
\text { DNA sequencing; sub-nanometer trans-electrode } \\
\text { membranes with potential applications to the } \\
\text { fabrication of very high resolution, high } \\
\text { throughput nanopore-based single-molecule } \\
\text { detectors; antibacterial activity of graphene, } \\
\text { graphite oxide, graphene oxide, and reduced } \\
\text { graphene oxide; nanopore sensors for nucleic } \\
\text { acid analysis; utilization of graphene multilayers } \\
\text { as the gates for sequential release of proteins } \\
\text { from the surface; utilization of graphene-based }\end{array}$ & [50] \\
\hline
\end{tabular}




\begin{tabular}{|l|l|l|}
\hline & $\begin{array}{l}\text { electro responsive scaffolds as implants for on- } \\
\text { demand drug delivery etc. }\end{array}$ & \\
\hline $\begin{array}{l}\text { Electrical control of bacteria-powered } \\
\text { microrobots }\end{array}$ & $\begin{array}{l}\text { Uses include delivering medication and } \\
\text { manipulating stem cells to direct their growth. }\end{array}$ & {$[26]$} \\
\hline $\begin{array}{l}\text { Polystyrene bead covered in gold and } \\
\text { chromium for nanorockets }\end{array}$ & $\begin{array}{l}\text { The body of the rocket was made from a } \\
\text { polystyrene bead covered in gold and chromium. } \\
\text { This was attached to multiple catalytic engine } \\
\text { molecules using strands of DNA. When placed } \\
\text { in a solution of hydrogen peroxide, the engine } \\
\text { molecules caused a chemical reaction that } \\
\text { produced oxygen bubbles, forcing the rocket to } \\
\text { move in the opposite direction. Shining a beam } \\
\text { of ultra-violet light on one side of the rocket } \\
\text { causes the DNA to break apart, detaching the } \\
\text { engines and changing the rocket's direction of } \\
\text { travel. The researchers hope to develop the } \\
\text { rocket so it can be used in any environment, for } \\
\text { example, to deliver drugs to a target area of the } \\
\text { body. }\end{array}$ & \\
\hline Albumin nanoparticle & $\begin{array}{l}\text { Macarena et. al presented the theoretical model } \\
\text { for the albumin NPs as a drug delivery system. } \\
\text { The albumin NPs is gamma irradiated. } \\
\text { Hydrophopic pockets are created to carry the } \\
\text { desirable drug to the site. The model presented a } \\
\text { controlled drug delivery. }\end{array}$ & \\
\hline
\end{tabular}

\section{Mechanism on the Function of Nanorobots}

Nanorobots are explored as the target-oriented drug delivery vehicle. The action of nanorobots has been investigated by different researchers. Kola et al. presented a hypothesis in which blood platelets are used as a drug delivery vehicle. Glioblastoma multiforme and ischemic stroke are the neurovascular problems associated with the brain and it is a bit difficult for a particular drug to reach the site because of the blood-brain barrier, generated by the endothelial cells. Platelets being biocompatible and biodegradable can encapsulate in a very efficient manner and when activation occurs in the presence of a tumor cell the granules and the encapsulated drug come out and starts its operation. For both Glioblastoma multiforme and ischemic stroke platelets aggregated at the site, get activated on its own natural property and release the drug, and treat the cancerous cells [52]. Zhao et al. presented hydrogel as a drug delivery vehicle. This is used to treat the problems associated with the human vasculature dysfunction. Narrowing of the vessels, blockage, and stroke are the key problem associated with it. Various proangiogenic growth factors and cytokines are used to treat these problems. The study shows that they are not as effective when delivered in a simple manner as compared to delivered through the hydrogels. Natural hydrogels like proteoglycans, protein fibers, or glycoproteins, and synthetic hydrogels like polysaccharide or polyethylene glycol are used as drug delivery vehicles. Natural hydrogels used, have the well established network and various interactions take place as hydrogen bonds formation, crystal 
formation, electrostatic and hydrophobic interactions. Synthetic hydrogels form stable covalent bonds with the polymer-cation interaction. Hydrogels help the protein drugs release in a sequential and time bound manner [53]. Francis et al. presented the study of immune cells to be utilized as an effective drug delivery vehicle. Immune cells have the inherent property of responding to the inflammation caused by the tumor cell. Due to this they swiftly move to the site and start irradiating the tumor cells. When the carefully designed NPs are joined with the immune cells, the efficiency of the treatment increased manifolds. When Ly6Chigh monocytes immune cells combined with the paclitaxelcontaining $\mathrm{pH}$-sensitive micelles their affinity to primary tumor increases and in a way they are used effectively against it.

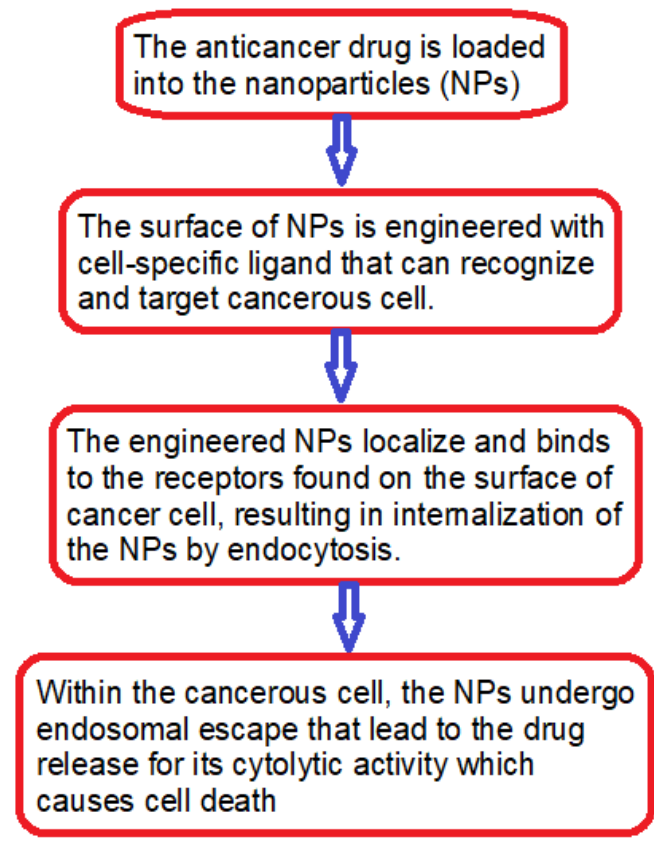

Fig. 5. Mechanism of action of a nanorobot for the treatment of cancerous cell $[56,57]$.

Their penetration to the affected site is much better than the others [54]. Madeh et al. presented the single walled carbon nanotube as a drug delivery vehicle. The anti-cancer drug used in this study is flutamide. Density functional theory (DFT) and molecular dynamic simulation (MD) are being used to qualify this study. As the study is being done in the water and gas environment, CNTs are used with carboxylic acid group to make it soluble in water. Moreover, the presence of a carboxylic acid group enhances the adsorption of anti-cancer drugs by the formed functional CNT significantly. In the computational method, the quantum mechanics calculations are done to find out the interaction between the molecules of CNT, carboxylic group, futamide, and water. In the molecular dynamics simulations different kind of CNTs are used to find out the 
interaction of it with the different available molecules. DFT theory provides a stable structure after the interaction. MD simulations also suggest a greater number of hydrogen bonds at the surface of different types of CNT used [55]. The mechanism of action of nanorobot for the treatment of cancerous cells is explained in Fig. 5 [56,57]. Some recent works on the mechanism/function, formulation, and types of nanorobots have been presented in Table 3.

Table 3. Some nanorobots and their formulation and mechanisms/functions.

\begin{tabular}{|c|c|c|c|}
\hline Nanorobots & Materials used & Functions & Ref. \\
\hline $\begin{array}{l}\text { Targeted nano drug } \\
\text { delivery systems }\end{array}$ & $\begin{array}{l}\text { Composite organic-inorganic NPs and } \\
\text { the quantum dots have advanced the } \\
\text { disease biomarkers }\end{array}$ & $\begin{array}{l}\text { Used for the treatment of } \\
\text { cancer }\end{array}$ & {$[56,57]$} \\
\hline $\begin{array}{l}\text { Nanotheranostics } \\
\text { against COVID-19 }\end{array}$ & Cellular nanosponges & $\begin{array}{l}\text { Biomarkers or drug } \\
\text { delivery towards the } \\
\text { pulmonary system or } \\
\text { other affected organs. }\end{array}$ & {$[58]$} \\
\hline $\begin{array}{l}4 \mathrm{D} \text { printing soft } \\
\text { robotics }\end{array}$ & $\begin{array}{l}\text { Shape memory polymers, shape } \\
\text { memory composites, and shape } \\
\text { memory hybrids }\end{array}$ & $\begin{array}{lr}\text { Biomedical } & \text { engineering } \\
\text { applications, } & \text { such as in } \\
\text { minimally } & \text { invasive } \\
\text { surgery. } & \end{array}$ & [59] \\
\hline $\begin{array}{ll}\text { Drug } & \text { delivery } \\
\text { vehicle } & \end{array}$ & $\begin{array}{l}\text { Various types of NPs and } \\
\text { nanostructures like, SPIONs }\end{array}$ & $\begin{array}{l}\text { (i) To achieve specific } \\
\text { targeting and controlled } \\
\text { drug release for the less } \\
\text { toxic and more effective } \\
\text { treatment especially for } \\
\text { cancer therapy. (ii) For } \\
\text { drug release at the tumor } \\
\text { site along with the } \\
\text { physical interaction of } \\
\text { NPs with cancer cells }\end{array}$ & {$[60]$} \\
\hline $\begin{array}{l}\text { Catalytic } \\
\text { microrobots }\end{array}$ & $\begin{array}{llllll}\text { Composed of (i) } & \mathrm{Fe}_{3} \mathrm{O}_{4} & \mathrm{NPs} & \text { (ii) } \\
\mathrm{TiO}_{2} / \mathrm{Pt} & & & & & \end{array}$ & To disrupt dental biofilm. & {$[61]$} \\
\hline $\begin{array}{ll}\text { Drug } & \text { delivery } \\
\text { vehicle } & \end{array}$ & Stimuli-responsive biomaterials & For wound healing. & [62] \\
\hline $\begin{array}{l}\text { Intelligent micro- } \\
\text { /nanorobots }\end{array}$ & $\begin{array}{l}\text { Nanoswimmers, nanoengines, 3D- } \\
\text { motion nanomachines, and } \\
\text { biologically inspired microbots, } \\
\text { nanofish, nanorockets }\end{array}$ & $\begin{array}{l}\text { Precision therapeutic } \\
\text { diagnoses, sensing, drug } \\
\text { delivery, and surgery. }\end{array}$ & [63] \\
\hline $\begin{array}{l}\text { DNA-nanorobot- } \\
\text { guided thrombin- } \\
\text { inducing tumor } \\
\text { infarction }\end{array}$ & $\begin{array}{l}\text { A tube-shaped DNA origami } \\
\text { nanostructure is used to deliver } \\
\text { thrombin into tumor vessels } \\
\text { selectively, where the thrombin is } \\
\text { positioned inside the inner cavity of } \\
\text { the nanorobot, protecting the highly } \\
\text { reactive molecule from the } \\
\text { interference of the blood circulation } \\
\text { and also minimizing its systemic } \\
\text { toxicities simultaneously, while on } \\
\text { the outside there is a DNA aptamer }\end{array}$ & $\begin{array}{l}\text { Used as a powerful } \\
\text { therapeutic strategy for } \\
\text { treatment of solid cancer }\end{array}$ & [64] \\
\hline
\end{tabular}




\begin{tabular}{|c|c|c|c|}
\hline & that binds nucleolin. & & \\
\hline DNA nanorobot & $\begin{array}{l}\text { The DNA nanorobot was constructed } \\
\text { by folding of DNA origami up to } 90 \\
\text { nm and conjugated with aptamer to } \\
\text { carry the blood coagulation protease } \\
\text { thrombin for target-specific action. } \\
\text { The unfolding of DNA nanorobot } \\
\text { occurs when it recognizes the tumor } \\
\text { cell by the aptamer and sense of } \\
\text { nucleolin B present in the tumor cells } \\
\text { for the release of thrombin to destruct } \\
\text { the tumor cell and suppress the } \\
\text { growth of the tumor. }\end{array}$ & $\begin{array}{l}\text { For the treatment of } \\
\text { tumors. }\end{array}$ & {$[65,66]$} \\
\hline Drug delivery & Dendrimers & $\begin{array}{l}\text { The structure of } \\
\text { dendrimers was } \\
\text { manipulated with } \\
\text { topological indices to } \\
\text { obtain the desired } \\
\text { properties to deliver the } \\
\text { drugs to target carrier } \\
\text { vehicle. The topological } \\
\text { indices of three different } \\
\text { dendrimers were studied } \\
\text { for the application in the } \\
\text { drug delivery system. }\end{array}$ & [67] \\
\hline
\end{tabular}

\section{Conclusion}

The development of nanorobots for the various biomedical areas would benefit from the advancements of efficient fuel-free and fuel-driven nanoscale machines. Magnetically powered nanoswimmers have attracted considerable attention due to their great biocompatibility. A high-speed magnetically-propelled nanowire swimmer which mimics swimming microorganisms by exploiting the flexible nanowire as artificial flagella under a rotating magnetic field has been established. New bioinspired microswimmers can alternatively be prepared directly from isolated spiral vessels of plants, harnessing the intrinsic biological structures of nature. Potential applications of these cargo-towing nanoswimmers are demonstrated by the directed delivery of drug-loaded microparticles to HeLa cancer cells in biological media. With such innovations and developments, along with careful attention to key challenges and requirements, nano/microscale motors are expected to have tremendous impact on diverse biomedical applications. It is hoped by the scientists that ultimately, the technology could create complex nano-robots to deliver medicine inside the body or perform nanoscale biological measurements, among many other applications. Also, like the fictional transformers, a DNA origami machine could change shape for different tasks.

In the future, the researchers hope to further scale down the size of Magneto Sperm which can be used in diverse biomedical applications such as in targeted drug delivery, in vitro fertilization, and cell sorting and cleaning of clogged arteries. The recent research performed by different group of workers make it possible to diagnose the cancer, applying 
a fabricated nanomachine based upon 3 dimensional DNA structure and the bacteria based drug delivery system that can automatically detect, move and can target the cancerous cells. The DNA has been established to work as a nanorobot to cargo the required material to the desirable location. DNA-nanorobot-guided thrombin inducing tumor infarction, which raises new potential clinical concerns, was developed. The work on potential applications of folded and unfolded DNA nanocarriers in medicine has also been carried out. Investigation on targeting nucleolin to obstruct vasculature feeding with an intelligent DNA nanorobot has also been done.

The work of nanorobots has extended on nanotheranostics against COVID-19, utilizing biomarkers or drug delivery towards the pulmonary system or other affected organs. 4D printing soft robotics has been explored in the minimally invasive surgery. Study on the spatiotemporal delivery of bioactive molecules for wound healing has been done applying stimuli-responsive biomaterials. A promising development opportunities and translational challenges have been provided by an intelligent nanorobot as drug and cell carrier devices.

The future perspectives of the utilization of nanorobots can be as follows:

(i) More research is required for the development of nanorobots for the application in the target oriented drug delivery.

(ii) The investigation on nanorobots should not be limited to the theory and simulation only. Practical application of it is required for the welfare of mankind.

(iii) At present circumstances, research on the use on nanorobots for the prevention and treatment of COVID-19 disease can be approached.

\section{References}

1. M. A. Zeeshan, K. Shou, K. M. K. Sivaraman, T. Wuhrmann, S. Pané, E. Pellicer, and B. J. Nelson, Mater. Today 14, 54 (2011). https://doi.org/10.1016/S1369-7021(11)70039-6

2. K. C. Mishra, Int. J. Adv. Eng. Technol. 4, 564 (2012).

3. G. Muthukumaran, U. Ramachandraiah, and D. G. H. Samuel. Adv. Mater. Res. 1086, 61 (2015). https://doi.org/10.4028/www.scientific.net/AMR.1086.61

4. H. S. Cho and T. H. Woo, Annals Nucl. Energ. 80, 429 (2015). https://doi.org/10.1016/j.anucene.2015.02.030

5. S. Martel, J. Nanopart. Res. 17, 75 (2015). https://doi.org/10.1007/s11051-014-2734-2

6. S. A. Wahajuddin and S. Arora, Int. J. Nanomed. 7, 3445 (2012). https://doi.org/10.2147/IJN.S30320

7. F. Qiu and B. J. Nelson, Engineering 1, 21 (2015). https://doi.org/10.15302/J-ENG-2015005

8. B. G. Nair, Y. Nagaoka, H. Morimoto, Y. Yoshida, T. Maekawa, and D. S. Kumar, Nanotechnology 21, ID 455102 (2010). https://doi.org/10.1088/0957-4484/21/45/455102

9. O. Felfoul, M. Mohammadi, S. Taherkhani, D. de Lanauze, Y. Zhong Xu, D. Loghin, S. Essa, S. Jancik, D. Houle, M. Lafleur, L. Gaboury, M. Tabrizian, N. Kaou, M. Atkin, T. Vuong, G. Batist, N. Beauchemin, D. Radzioch, and S. Martel, Nature Nanotechnol. 11, 941 (2016). https://doi.org/10.1038/nnano.2016.137

10. P. Vaupel, A. Mayer, Cancer Metastasis Rev. 26, 225 (2007). https://doi.org/10.1007/s10555007-9055-1

11. R. B. Frankel, D. A. Bazylinski, M. S. Johnson, and B. L. Taylor. Biophys. J. 73, 994 (1997). https://doi.org/10.1016/S0006-3495(97)78132-3

12. R. P. Blakemore, Science 190, 377 (1975). https://doi.org/10.1126/science. 170679 
13. D. A. Bazilinski, T. J. Williams, C. T. Lefevre, R. J. Berg, C. L. Zhang, S. S. Bowser, A. J. Dean, and T. J. Beveridge, Int. J. Syst. Evol. Microbiol. 63, 801 (2013). https://doi.org/10.1099/ijs.0.038927-0

14. D. A. Bazylinski, R. B. Frankel, and H. W. Jannasch, Nature 334, 518 (1988). https://doi.org/10.1038/334518a0

15. C. T. Lefèvre, M. Bennet, L. Landau, P. Vach, D. Pignol, D. A. Bazylinski, R. B. Frankel, S. Klumpp, and D. Faivre, Biophys. J. 107, 527 (2014). https://doi.org/10.1016/j.bpj.2014.05.043

16. T. Sen, University of Central Lancashire 2016. http://phys.org/news/2016-04-nanomachinesmedical-revolution.html\#jCp

17. T. Kondo and W. Kasai, J. Biosci. Bioeng. 118, 482 (2014). http://dx.doi.org/10.1016/j.jbiosc.2014.04.002

18. A. E. Marras, L. Zhou, H. -J. Su, and C. E. Castro, PNAS 112, 713 (2015). https://doi.org/10.1073/pnas.1408869112

19. P. Yang, K. W. Zhang, X. Peng, Y. Q. Chai, R. Yuan, and W. B. Liang. Analytica Chimica Acta 1126, 24 (2020). https://doi.org/10.1016/j.aca.2020.06.004

20. B. Jang, E. Gutman, N. Stucki, B. F. Seitz, P. D. Wendel-García, T. Newton, J. Pokki, O. Ergeneman, S. Pané, Y. Or, and B. J. Nelson, Nano Lett. 15, 4829 (2015). https://doi.org/10.1021/acs.nanolett.5b01981

21. N. Zoaby, J. S. Roitman, S. Badarneh, H. A. Manhal, A. Leshansky, S. Yaron, and A. Schroeder, J. Control. Rel. 257, 68 (2016). https://doi.org/10.1016/j.jconrel.2016.10.006

22. X. Yan, J. Xu, Q. Zhou, D. Jin, C. I. Vong, Q. Feng, D. H. L. Ng, L. Bian, and L. Zhang, Appl. Mater. Today 15, 242 (2019). https://doi.org/10.1016/j.apmt.2019.02.006

23. T. Ding, V. K. Valev, A. R. Salmon, C. J. Forman, S. K. Smoukov, O. A. Schermand, D. Frenkel, and J. J. Baumberg, PANS 113, 5503 (2016). https://doi.org/10.1073/pnas.1524209113

24. S. Islam. M. Khalil, C. Herman. Dijkslag, L. Abelmann, and S. Misra. Appl. Phys. Lett. 104, ID 223701 (2014). https://doi.org/10.1063/1.4880035

25. E. Torelli, M. Manzano, S. K. Srivastava, and R S. Marks, Biosens. Bioelectron. 99, 209 (2018). https://doi.org/10.1016/j.bios.2017.07.051

26. H. Kim and M. J. Kim, IEEE Transact. Robotics 32, 125 (2016). https://doi.org/10.1109/TRO.2015.2504370

27. H. S. Cho and T H Woo, Annals of Nucl. Energy (2015).

28. T. Sen, Meet the Nanomachines That Could Drive a Medical Revolution, Singularity Hub News (2016). https://theconversation.com/meet-the-nanomachines-that-could-drive-a-medicalrevolution-58107

29. R. Liu and A. Sen. J. Am. Chem. Soc. 133, 20064 (2011). https://doi.org/10.1021/ja2082735

30. C. Karthikeyan, K. Varaprasad, A. A. Fakhrabadi, A. S. H. Hameed, and R Sadiku, Carbohydr. Polym. 249, ID 116825 (2020). https://doi.org/10.1016/j.carbpol.2020.116825

31. G. Kumar, A. Kantb, M. Kumar, and D. T. Masram, Inorganica Chimica Acta 496, ID 119036 (2019). https://doi.org/10.1016/j.ica.2019.119036

32. F. P. Aghaei, M. Mohammadi, and S. E. Roozmeh, J. Mol. Graph. Modell. 90, 33 (2019). https://doi.org/10.1016/j.jmgm.2019.03.020

33. P. K. Gupta, S. K. Tripathi, S. Pappuru, S. C. Chabattula, K. Govarthanan, S. Gupta, B. K. Biswal, D. Chakraborty, and R. S. Verma, Mater. Sci. Eng. C 107, ID 110285 (2020). https://doi.org/10.1016/j.msec.2019.110285

34. M. Sun, X. Yu, T. Wang, S. Bi, Y. Liu, and X. Chen, Int. J. Biol. Macromol. 135, 1182 (2019). https://doi.org/10.1016/j.ijbiomac.2019.05.188

35. S. Baek, R. K. Singh, D. Khanal, K. D. Patel, E. J. Lee, K. W. Leong, W. Chrzanowski, and H. W. Kim, Nanoscale 7, 14191 (2016). https://doi.org/10.1039/C5NR02730F

36. J. A. Webb and R. Bardhan, Nanoscale 6, 2502 (2014). https://doi.org/10.1039/c3nr05112a

37. K. J. Chen, PhD thesis, University of California, USA (2012).

38. J. Gibbs and Y. Zhao, Catalytic Nanomotors: Challenges and Opportunities - Proc. of the SPIE, 8058 (2011) 80580O. https://doi.org/10.1117/12.887526 
39. L. Soler and S. Sánchez, Nanoscale 6, 7175 (2014). https://doi.org/10.1039/C4NR01321B

40. G. Yang, D. D. Chengzhou, J. Zhu, and Y. Lin. Nanoscale 7, 14217 (2015). https://doi.org/10.1039/C5NR03398E

41. F. Wong and K. K. Dey, Annual Rev. Mater. Res. 46, 407 (2016). https://doi.org/10.1146/annurev-matsci-070115-032047

42. A. Aires, S. M. Ocampo, B. M. Simões, R. M. Josefa, J. F. Cadenas, P. Couleaud, K. Spence, A. Latorre, R. Miranda, A. Somoza, R. B. Clarke, J. L. Carrascosa, and A. L. Cortajarena, Nanotechnology 27, ID 065103 (2016). https://doi.org/10.1088/0957-4484/27/6/065103

43. M. Hoop, F. Mushtaq, C. Hurter, X. Z. Chen, B. J. Nelson, and S. Pané, Nanoscale 8, 12723 (2016). https://doi.org/10.1039/C6NR02228F

44. J. Gibbs and Y. Zhao. Front. Mater. Sci. 5, 25 (2011). https://doi.org/10.1007/s11706-011$\underline{0120-\mathrm{x}}$

45. R. Kapral, J. Chem. Phys. 138, ID 020901 (2013). https://doi.org/10.1063/1.4773981

46. T. Maldiney, B. Ballet, M. Bessodes, D. Scherman, and C. Richard, Nanoscale 6, 13970 (2014). https://doi.org/10.1039/C4NR03843F

47. Y. Cao, M. Gao, C. Chen, A. Fan, J. Zhang, D. Kong, Z. Wang, D. Peer, and Y. Zhao, Nanotechnology 26, ID 115101 (2015). https://doi.org/10.1088/0957-4484/26/11/115101

48. M. Colone, S. Kaliappan, A. Calcabrini, M. Tortora, F. Cavalieri, and A. Stringaro, Drug Delivery System and Breast Cancer Cells - AIP Conf. Proc. 1749, ID 020013 (2016). https://doi.org/10.1063/1.4954496

49. V. V. Singh and J. Wang. Nanoscale 7, 19377 (2015). https://doi.org/10.1039/C5NR06254C

50. B. H. Nguyen and H. Nguyen. Adv. Natural Sci.: Nanosci. Nanotechnol. 7, ID 023002 (2016). https://doi.org/10.1088/2043-6262/7/2/023002

51. M. Siri, M. Grasselli, and S. D. V. Alonso, Colloids and Surfaces A 603, ID 125176 (2020). https://doi.org/10.1016/j.colsurfa.2020.125176

52. S. M. Kola, P. Kumar, Y. E. Choonara, L. C. du Toit, and V. Pillay, Medical Hypotheses 125, 75 (2019). https://doi.org/10.1016/j.mehy.2019.02.037

53. Z. Wei, E. Volkova, M. R. Blatchley, and S. Gerecht, Adv. Drug Deliv. Rev. 149-150, 95 (2019). https://doi.org/10.1016/j.addr.2019.08.005

54. F. Combes, E. Meyer, and N. N. Sanders, J. Control. Rel. 327, 70 (2020). https://doi.org/10.1016/j.jconrel.2020.07.043

55. M. Kamel, H. Raissi, A. Morsali, and M. Shahabi, Appl. Surface Sci. 434, 492 (2018). https://doi.org/10.1016/j.apsusc.2017.10.165

56. M. Srinivasan, M. Rajabi, and S. A. Mousa, Nanomaterials 5, 1690 (2015). https://doi.org/10.3390/nano5041690

57. H. A. Adeola, S. Sabiu, T. A. Adekiya, R. T. Aruleba, C. E. Aruwa, and B. E. Oyinloye, Heliyon 6, ID e04890 (2020). https://doi.org/10.1016/j.heliyon.2020.e04890

58. P. Hassanzadeh, J. Control. Rel. 328, 112 (2020). https://doi.org/10.1016/j.jconrel.2020.08.060

59. S. Y. Hann, H. Cui, M. Nowicki, and L. G. Zhang, Additive Manufacturing 36, 101567 (2020). https://doi.org/10.1016/j.addma.2020.101567

60. A. V. V. Nikezić, A. M. Bondžić, and V. M. Vasić, Eur. J. Pharmaceut. Sci. 151, 105412 (2020). https://doi.org/10.1016/j.ejps.2020.105412

61. K. Villa, J. Viktorova, J. Plutnar, T. Rum, L. Hoang, and M. Pumera, Cell Rep. Phys. Sci. 1, 100181 (2020). https://doi.org/10.1016/j.xcrp.2020.100181

62. N. Oliva and B. D. Almquist, Adv. Drug Deliv. Rev. (2020). https://doi.org/10.1016/j.addr.2020.07.021

63. V. Agrahari, M. L. Chou, C. H. Chewc, J. Noll, and T. Burnouf, Biomaterials 260, ID 120163 (2020). https://doi.org/10.1016/j.biomaterials.2020.120163

64. K. Zheng, J. M. Kros, J. Li, and P. P. Zheng, Drug Discovery Today 25, (2020). https://doi.org/10.1016/j.drudis.2020.03.005

65. P. Shende and I. Kataria, J. Drug Deliv. Sci. Technol. 57, ID 101729 (2020). https://doi.org/10.1016/j.jddst.2020.101729 


\section{Review Article: Utilization of Nanomaterials}

66. H. Li, J. Liu, and H. Gu, J. Cell Mol. Med. 23, 2248 (2019).

https://doi.org/10.1111/jcmm.14127

67. T. P. Jude, E. Panchadcharam, and K. Masilamani, J. Sci. Res. 12, 645 (2020).

https://doi.org/10.3329/jsr.v12i4.45389 